\title{
Trends in Tissue Engineering for Blood Vessels
}

\author{
Judee Grace Nemeno-Guanzon, ${ }^{1}$ Soojung Lee, ${ }^{1}$ Johan Robert Berg, ${ }^{1,2}$ Yong Hwa Jo, ${ }^{1}$ \\ Jee Eun Yeo, ${ }^{1,3}$ Bo Mi Nam, ${ }^{1}$ Yong-Gon Koh, ${ }^{3}$ and Jeong Ik Lee ${ }^{1}$ \\ ${ }^{1}$ Regenerative Medicine Laboratory, Stem Cell Research Center, Department of Biomedical Science and Technology, \\ SMART Institute of Advanced Biomedical Science, Konkuk University, 143-701 Seoul, Republic of Korea \\ ${ }^{2}$ Department of Chemical and Biological Engineering, Chalmers University of Technology, SE 41296 Gothenburg, Sweden \\ ${ }^{3}$ Department of Orthopedic Surgery, Yonsei Sarang Hospital, 137-820 Seoul, Republic of Korea \\ Correspondence should be addressed to Jeong Ik Lee, jeongik@konkuk.ac.kr
}

Received 18 July 2012; Accepted 25 September 2012

Academic Editor: Brynn Levy

Copyright () 2012 Judee Grace Nemeno-Guanzon et al. This is an open access article distributed under the Creative Commons Attribution License, which permits unrestricted use, distribution, and reproduction in any medium, provided the original work is properly cited.

\begin{abstract}
Over the years, cardiovascular diseases continue to increase and affect not only human health but also the economic stability worldwide. The advancement in tissue engineering is contributing a lot in dealing with this immediate need of alleviating human health. Blood vessel diseases are considered as major cardiovascular health problems. Although blood vessel transplantation is the most convenient treatment, it has been delimited due to scarcity of donors and the patient's conditions. However, tissueengineered blood vessels are promising alternatives as mode of treatment for blood vessel defects. The purpose of this paper is to show the importance of the advancement on biofabrication technology for treatment of soft tissue defects particularly for vascular tissues. This will also provide an overview and update on the current status of tissue reconstruction especially from autologous stem cells, scaffolds, and scaffold-free cellular transplantable constructs. The discussion of this paper will be focused on the historical view of cardiovascular tissue engineering and stem cell biology. The representative studies featured in this paper are limited within the last decade in order to trace the trend and evolution of techniques for blood vessel tissue engineering.
\end{abstract}

\section{Introduction}

Many recent studies have focused on cell therapies, scaffold based and cell based, for cardiovascular diseases primarily because these pathologies still rank among the top ten leading causes of mortality and morbidity worldwide. Annually, thousands of people die due to myocardial infarction, congestive heart failure, stroke, valvular heart diseases, and vascular diseases. According to the recent report of the American Heart Association, in 2008, an average of one death occurred every 39 seconds accounting to more than 2200 American deaths due to cardiovascular diseases (CVD) each day, with greater rate among black than white Americans [1]. Bearing in mind that the administration of various drugs caused a number of chemical reactions in the body and even led to autoimmune complications instead of treating the primary disease, it is therefore noteworthy that advancements on regenerative medicine and tissue engineering are highly beneficial. Tissue engineering and regenerative medicine do not only offer fast recovery but also lessen the medical and economic burden among the patients suffering from cardiovascular diseases.

At present, a vast of information and techniques on biofabrication and stem cell biology have been established; however, the effectiveness based on the clinical applications of these techniques remains to be elucidated. This paper will highlight the updates of regenerative medicine and tissue engineering techniques which addressed cardiovascular diseases. In particular, this will include the evolution of scaffold and scaffold-free cell therapies for the blood vessel defects as well as the various stem cells used for engineering blood vessels. The updates on tissue engineering for heart valve and the myocardium will be reviewed subsequent to this paper. 


\section{History of Tissue Engineering for Cardiovascular Tissues}

It is globally known that in the developed countries, cardiovascular diseases are the primary causes of mortality and morbidity. Based on the review done by Zaragosa et al., both genetic and environmental factors are associated with the cardiac and vascular complications. Therefore, these complex multifactorial pathologies are very difficult to prevent [2]. Although prior papers emphasized that new drugs and innovative devices have improved quality of life for patients inflicted with cardiovascular diseases, they have not necessarily reduced the mortality and morbidity rate [3]. Then, organ transplantation provided a new therapeutic path. Transplantation offers an immediate "cure" by replacing the damaged tissues or organs with normally functional substitutes [4]. Since it is the preferred treatment for organ failure, there is a growing need for transplantable human organs, either autologous or from certain donors [5]. However, there are two major lifelong obstacles that have restricted organ transplantation, namely, the critical paucity of donors and the high risk of graft rejection [6]. In fact, successful treatment to cardiovascular diseases has been limited due to lack of suitable autologous tissue to restore injured cardiac muscles or to serve as vascular conduits to replace or bypass diseased or occluded vessels. On the other hand, the immunosuppressive agents bridged the mortality and morbidity of the organ failure to the risk of infection, cancer, and cardiovascular diseases $[3,4]$. Hence, tissue engineering has been projected as an alternative treatment to these problems by replacing the damaged tissue or organ function with constructs which are biofabricated based on the required tissue or organ features [3]. In particular, cardiovascular tissue engineering is more valuable and relevant compared to other fields of tissue engineering mainly because it increases life expectancy, preserve, the extremities, and caters a vast number of patients [7].

Tissue engineering is an interdisciplinary field that applies the principles of engineering and life sciences towards the development of functional substitutes for damaged tissues. It is anchored on the fundamental concept of utilizing the body's natural biological response to tissue damage in conjunction with engineering principles $[8,9]$. In addition, tissue engineering is designed to produce biomimetic constructs, which resemble normal tissues, to replace the damage tissues. Moreover, the main objective of tissue engineering is the restoration of function through the delivery of living elements which become integrated in the patient [10].

Tissue engineering strategies have three basic components: firstly, the cells or source which must express the appropriate genes and maintain the appropriate phenotype in order to preserve the specific function of the tissue [11], secondly, the bioreactive agents or signals that induce cells to function, and thirdly, the scaffolds that house the cells and act as substitute for the damaged tissue [12]. The source may either be embryonic stem cells (ESC) or adult stem cells (ASC) in origin, the scaffolds may be categorized as synthetic, biological, or composite, and the signals may include growth factors/cytokines, adhesion factors, and bioreactors [13]. In many studies, the tissue engineering components have been considered and explored focusing on single component only (S component only- source, scaffold, or signal only), or in combination (S-S components- Scaffold/Signal, Scaffold/Source, and Signal/Source), or altogether (S-S-SSource, Scaffold, and Signal) (Figure 1).

Currently, the evolution of bottom-up and top-down approaches (Figure 2) in tissue engineering has been continuously investigated by many groups as the most promising tissue engineering approaches. The bottom-up approach usually employs implantation of precultured cells and synthetic scaffold complexes into the defect area. The cells or source, generally isolated from host target tissues, are expanded in vitro and preseeded into the scaffold to provide a porous three-dimensional structure that accommodate the seeded cells and form extracellular matrix. [9, 14-17]. Subsequently multiple methods such as cell aggregation, microfabrication, cell sheeting, and cell printing are utilized in generating modular tissues. They are then assembled through random assembly, stacking of cell sheets, or directed assembly into engineered tissues with specific microarchitectural features. Thereafter, the engineered tissue is transplanted into the defected area. Therefore, this approach allow, scientists to finely transform the nanostructure of materials by balancing polymer degradation rates with the extracellular matrix (ECM) production and cellular infiltration which caused the increased cell binding sequences, enzymatic cleavage sites, and tethering of chemoattractant molecules [17-20]. Conversely, in the top-down approach, there are two ways to manufacture the engineered tissue: (1) cells and biomaterial scaffolds are combined and cultured until the cells fill the support structure to create an engineered tissue [17] or (2) the acellular scaffolds, incorporated with biomolecules, are delivered immediately after injury. The biomolecules are released from scaffolds in a controlled manner, and they may recruit the progenitor cells in injured area and promote their proliferation and differentiation and eventually repair the injured tissues $[9,14-16]$.

\section{Blood Vessel Structure, Functions, and Cell Sources}

Blood vessels extend throughout the body and mediate gas exchange, nutrient and waste transport, and immune defense. The blood vessels consist of endothelial cells that are in contact with the blood, vascular smooth muscle cells that cover the endothelial cells as well as form the middle layer, and the fibroblasts and matrix that form the vessels' outer layer. Based on the earlier evaluation, cells of the blood vessels perform different functions in relation to cardiovascular physiology (Figure 3) [21-29]. Altogether, these layers of cells play a role in repairing, remodeling, and maintaining the blood vessels following an injury. All these cell types have been involved not only in cardiovascular pathology but also in therapy. In a recent review, Chen et al. pointed out that human blood vessel-derived stem cells are utilized as sources for tissue repair and regeneration for various cardiac and muscular diseases. The myogenic endothelial cells are involved in muscular regeneration and 


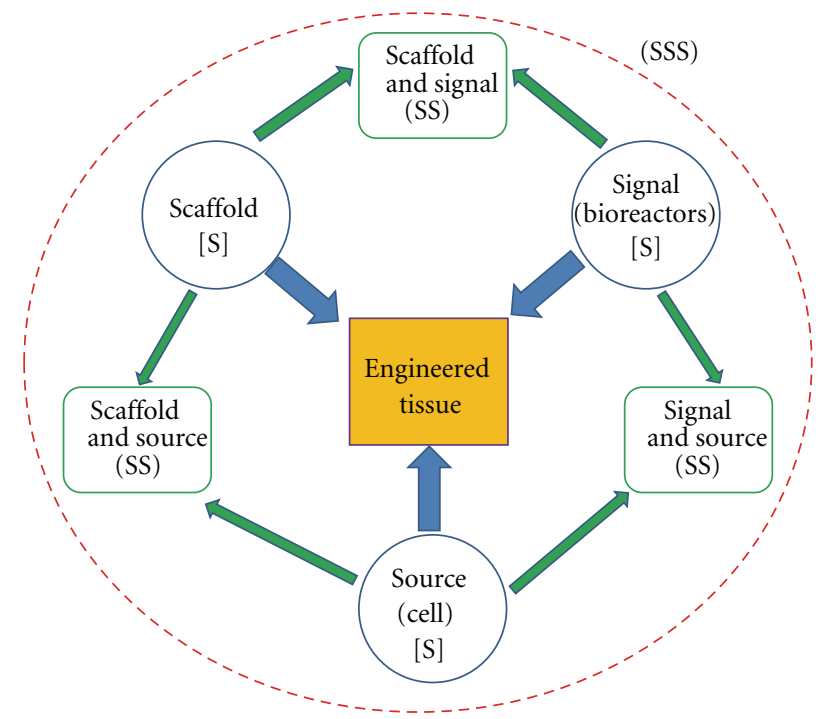

FIGURE 1: Tissue engineering triad of cells or source, signals (provided chemically by growth factors/cytokines or physically by a bioreactor), and the scaffold which acts as a template for tissue formation allowing the cells to migrate, adhere, and produce tissue. These components make up the Triple S (Source, Scaffold, and Signal) of tissue engineering. Any combination of these triad components has been considered in various studies in cell therapy which accounts for SS (Scaffold/Signal, Scaffold/Source, and Signal/Source). Finally, these three components (Source, Scaffold, and Signal or SSS) have also been considered altogether in some research projects.

“Bottom-up" approach

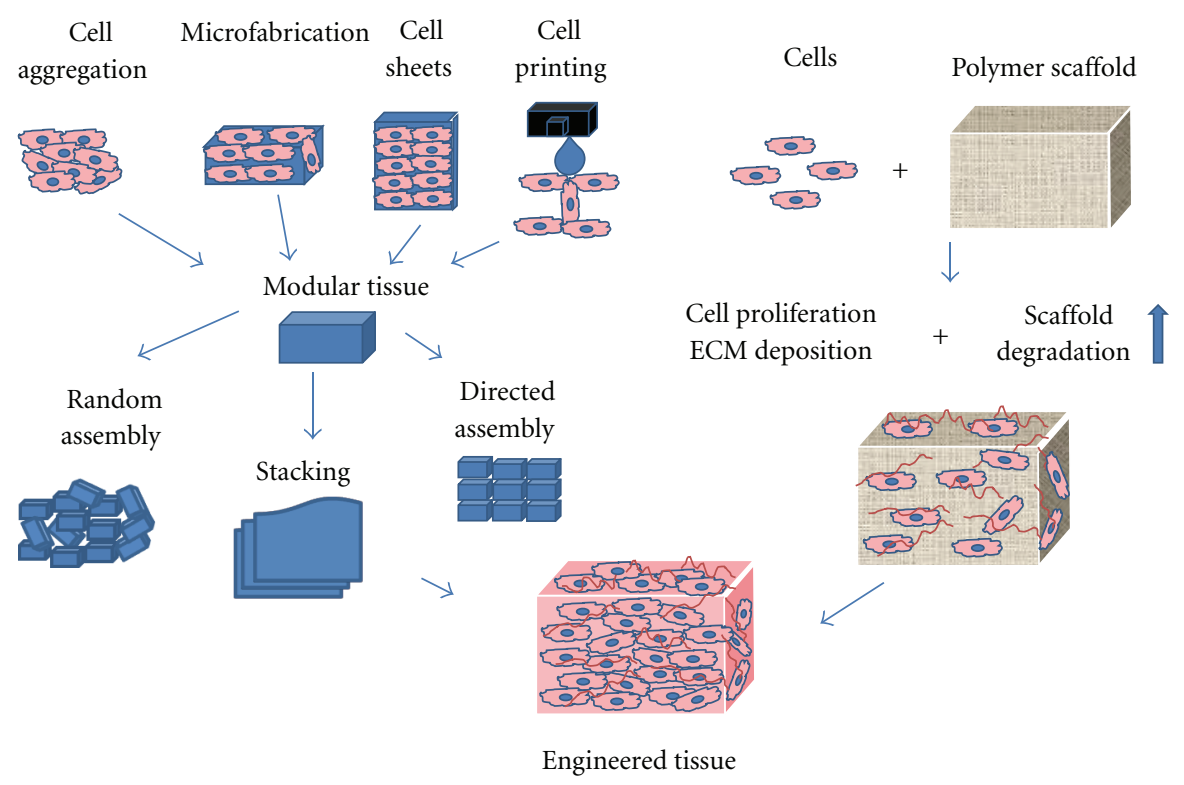

FIGURE 2: Bottom-up and Top-down approaches to tissue engineering. In the bottom-up approach there are multiple methods for creating modular tissues, which are then assembled into engineered tissues with specific microarchitectural features. In the top-down approach, cells and biomaterial scaffolds are combined and cultured until the cells fill the support structure to create an engineered tissue. Nichol, J. W. and Khademhosseini, A. 2009, Page 10 Soft Matter. Reproduced by permission of The Royal Society of Chemistry.

cardiac repair particularly in acute myocardial infarction; the pericytes, on the other hand, contribute to the regeneration of dystrophic skeletal muscles, while the adventitial cell participates in vascular remodeling and regeneration of the surrounding tissues $[28,30,31]$.
Blood vessel diseases such as atherosclerosis and arteritis $[30,32]$, Chronic Venous Insufficiency (CVI) [33], and thrombosis remain as major vascular problems globally. Hence, the increasing morbidity of cardiovascular diseases in the modern society has made it crucial to develop blood 


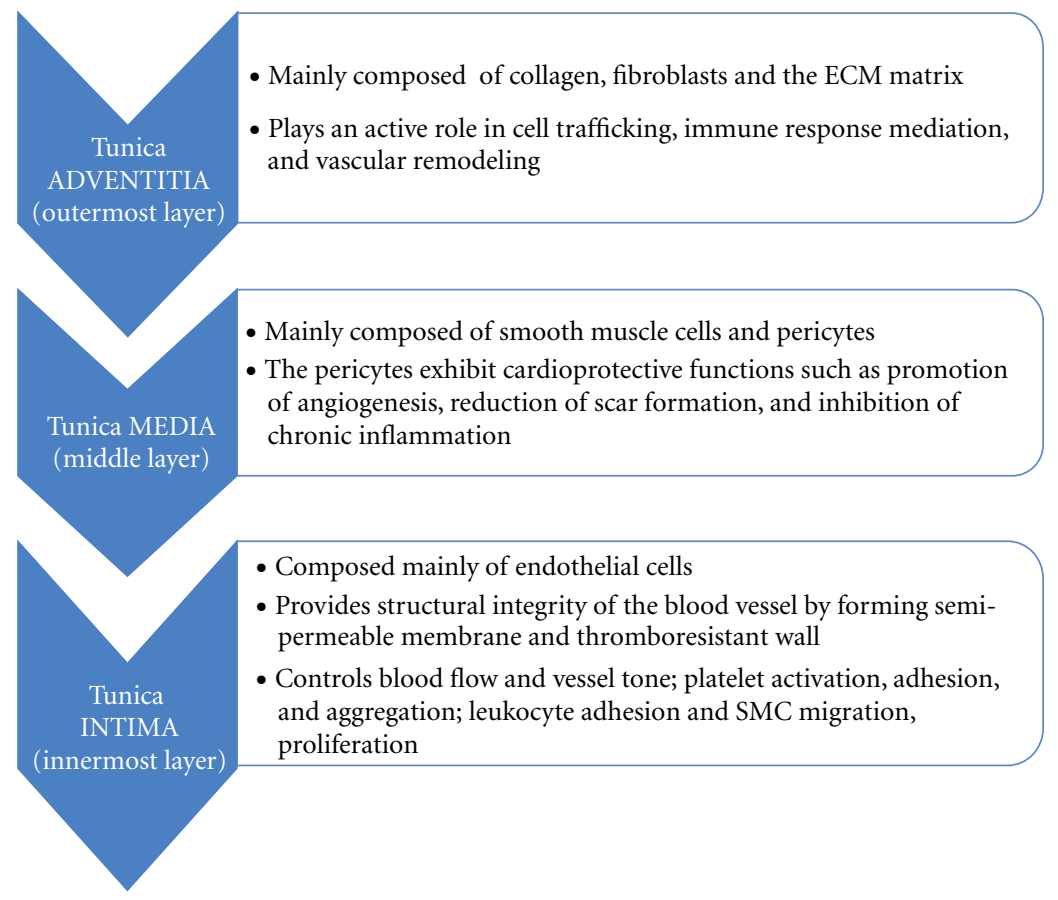

Figure 3: Main Tunicae of the blood vessels. Outer Tunica Adventitia, middle Tunica Media, and inner Tunica Intima, their corresponding cell composition and functions.

vessel substitutes especially for those small diameter vessels (less than $6 \mathrm{~mm}$ ) for the replacement of diseased coronary and below the knee vessels. Current therapies for such diseases include surgical replacement with autologous vessels or synthetic materials $[34,35]$.

Although autologous vessels remain the standard for small grafts, many patients have a limited vessel suitable for use because of vascular disease, amputation, or previous harvest [36]. Despite a clear clinical need for a functional arterial graft, success has been limited to arterial replacements of large-caliber vessels such as the thoracic and abdominal aorta, arch vessels, iliac, and common femoral arteries; however, small-caliber arterial substitutes, which account for a majority of the demand, have generally proved inadequate largely because of acute thrombogenicity of the graft, anastomotic intimal hyperplasia, aneurysm formation, infection, and progression of artherosclerotic disease [37]. From this time, tissue engineering is the promising approach to address the shortcomings of such treatment $[36,37]$.

Although advances in vascular tissue engineering have had limited clinical application because of the cell's limited replicative capacity, loss of telomerase activity of adult somatic cells, and the long-term production of the biological construct $[38,39]$, many investigators have further explored techniques with the objective of fabricating biomimetic tissue-engineered blood vessels (TEBV). Creating an engineered blood vessel substitute requires the incorporation of both smooth muscles and endothelial cells into the tubular scaffold so as to establish an architecture like that of a native blood vessel [40]. The first production of completely biological tissue-engineered blood vessels, composed of intima, media, and an adventitia, using cultured mature smooth muscle cells and endothelial cells in bovine collagen gels was pioneered by Weinberg and Bell [41] and this rapidly expanded the number of studies akin to blood vessel diseases. It is now well known that the smooth muscle layer of the blood vessel plays an important role in maintaining homeostasis of blood vessels [42]. Additionally, vascular smooth muscle cells do not only play important roles in the physiological function of the blood vessels but also in their remodeling under pathological conditions [31]. Thus, generating functional smooth muscle layer is a prerequisite for successful blood vessel construction through tissue engineering approach. Smooth muscle cells and endothelial cells were the early sources broadly utilized to construct vascular implants $[42,43]$. Nevertheless, due to the limited proliferation ability and loss of contractile phenotype of mature-differentiated smooth muscle cells (SMCs), various alternative sources of cells have been explored for the production of blood vessel replacements. Their corresponding characteristics, some of these were previously described, [42] are summarized in Table 1.

\section{Scaffolds for Blood Vessels}

To date, despite numerous scaffolds that have been manufactured through varied forms of tissue engineering techniques, the construction of an entirely biomimetic blood vessels is still underway. To achieve a successful clinical application of tissue-engineered blood vessels, the biofabrication of vascular grafts necessitates a vigorous yet time-efficient biotechnological process [39]. Several tissue engineering 
TABLE 1: Stem cells for tissue engineering of blood vessel, their advantages and disadvantages.

\begin{tabular}{|c|c|c|c|}
\hline Cells & Advantages & Disadvantages & References \\
\hline $\begin{array}{l}\text { Mesenchymal Stem Cells } \\
\text { (MSCs) }\end{array}$ & $\begin{array}{l}\text { (i) self-renewal capacity } \\
\text { (ii) long-term viability } \\
\text { (iii) pluripotent }\end{array}$ & $\begin{array}{l}\text { (i) low frequencies of existence } \\
\text { (ii) time-consuming expansion } \\
\text { (iii) harvesting complications }\end{array}$ & {$[44]$} \\
\hline $\begin{array}{l}\text { ASCs (adipose-derived } \\
\text { stem cells) }\end{array}$ & $\begin{array}{l}\text { (i) superior multi-differentiation potential } \\
\text { (ii) easily acquired with minimally invasive } \\
\text { technique } \\
\text { (iii) have lower donor-site morbidity } \\
\text { (iv) abundant and practical } \\
\text { (v) rapid in vitro expansion } \\
\text { (vi) multipotency is independent of the } \\
\text { donor's age } \\
\text { (vii) secrete several angiogenesis-related } \\
\text { factors and therefore induce angiogenesis }\end{array}$ & $\begin{array}{l}\text { (i) susceptible to apoptosis during isolation } \\
\text { (ii) cell expansion requires growth factors }\end{array}$ & [45-51] \\
\hline $\begin{array}{l}\text { Embryonic stem cells } \\
\text { (ESCs) }\end{array}$ & $\begin{array}{l}\text { (i) pluripotent } \\
\text { (ii) may differentiate to SMC }\end{array}$ & $\begin{array}{l}\text { (i) low induction efficiency } \\
\text { (ii) low smooth muscle cell (SMC) purity }\end{array}$ & {$[43,52]$} \\
\hline $\begin{array}{l}\text { Endothelial progenitor } \\
\text { cells (EPCs) }\end{array}$ & $\begin{array}{l}\text { (i) have exponential proliferation rate } \\
\text { (ii) involved in hemostasis, angiogenesis, } \\
\text { and arterial injury and endothelium repair } \\
\text { (iii) can be evaluated in vivo in Baboon } \\
\text { model } \\
\text { (iv) promote neovascularization in ischemic } \\
\text { tissue, coating of vascular grafts, seeding } \\
\text { hybrid grafts } \\
\text { (v) can be harvested prenatally and } \\
\text { noninvasively }\end{array}$ & $\begin{array}{l}\text { (i) unknown in vivo EPC differentiation and } \\
\text { migration signals and homing to the sites } \\
\text { of injured endothelium or extravascular } \\
\text { area } \\
\text { (ii) EPCs from high risk cardiovascular } \\
\text { patients have higher rates of in vitro } \\
\text { senescence }\end{array}$ & [53-62] \\
\hline
\end{tabular}

(i) readily accessible autologous cell source

(ii) BMC aspiration is less invasive and associated with much lower morbidity at

Bone marrow cells (BMCs)

the donor sites

(iii) have the potential to regenerate vascular tissues

(iv) improve patency in tissue-engineered small-diameter vascular grafts

Human artery-derived fibroblast (HAFs)

(i) promotes enhanced ECM formation and maturation

(i) important in endothelialization after transplantation

(ii) prevent platelet adhesion

Human umbilical cord vein endothelial cells (HUVEC)

(iii) largely and routinely cultured from a
readily available supply of discarded tissue

(iv) have reproducible and enhanced angiogenesis capacity (in vitro) (i) may induce calcification and thrombus formation

$[63,64]$
$[39,65,66]$ (i) time-consuming isolation

cell culture includes risk of infection and

(iii) low proliferative capacity strategies have emerged to address biological flaws at the blood-material interface of the synthetic scaffolds, hence, paving the way to vascular cell seeding and design of bioactive polymers for in situ regeneration. Moreover, advances in biomaterial design have been directed towards the generation of suitable materials that does not only mimic the native vascular tissue's mechanical properties but also promote cell growth, inhibit thrombogenicity, and facilitate extracellular matrix production [18]. In addition, an important characteristic of artificial scaffolds in advanced biomaterial vessel substitutes is not just the tolerance of the cells but the capacity to mimic the natural ECM in order to regulate extent and strength of cell adhesion, growth activity, cell differentiation, and maturation to the desired phenotype [84-86]. The extracellular matrix proteins such as collagen, elastin, fibronectin, vitronectin, and laminins which mediate cell-material adhesion have been thoroughly assessed in an earlier review [31].

Materials for vascular replacements should be biomimetic in such a way that they should be resistant not only to thrombosis, but also to inflammation, and neointimal proliferation, and for all intents and purposes, they should resemble the native vessels $[3,31]$. For these reasons, it is necessary to investigate the physical, chemical, and 
TABLE 2: Representative studies on scaffold-based tissue-engineered blood vessels.

\begin{tabular}{|c|c|c|c|c|c|}
\hline $\begin{array}{l}\text { Publication } \\
\text { year }\end{array}$ & Scaffold & Source/signal & Reported results & Type of study & References \\
\hline 1999 & $\begin{array}{l}\text { Tubular } \\
\text { biodegradable } \\
\text { polyglycolic acid } \\
\text { (PGA) scaffolds }\end{array}$ & $\begin{array}{l}\text { SMC and ECs from } \\
\text { bovine aorta/pulsatile } \\
\text { perfusion system in } \\
\text { a bioreactor with } \\
\text { supplemented medium }\end{array}$ & $\begin{array}{l}\text { (1) the gross appearance of the vessels was } \\
\text { identical to that of native arteries } \\
\text { (2) SMCs migrated inward to envelop PGA } \\
\text { fragments in the vessel wall, resulting in } \\
\text { a smooth luminal surface onto which } \\
\text { bovine aortic endothelial cells were } \\
\text { easily seeded } \\
\text { (3) the bioreactor system increased the } \\
\text { vessel wall thickness and suture retention } \\
\text { strengths, as well as influenced the } \\
\text { vessel's contraction } \\
\text { (4) four weeks after implantation, } \\
\text { autologous explants showed highly } \\
\text { organized structure and minimal } \\
\text { inflammation }\end{array}$ & $\begin{array}{l}\text { in vitro } \\
\text { in vivo in } \\
\text { swine model }\end{array}$ & {$[67]$} \\
\hline 2000 & $\begin{array}{l}\text { Microvessels with } \\
\text { fibronectin-collagen } \\
\text { 3D gels }\end{array}$ & $\begin{array}{l}\text { Umbilical vein } \\
\text { endothelial cells } \\
\text { (HUVEC)/Bcl-2 }\end{array}$ & $\begin{array}{l}\text { (1) human umbilical-vein EC (HUVEC) } \\
\text { within mixed fibronectin-collagen 3D } \\
\text { gels induced tube formation } \\
\text { (2) remarkable inosculation of these } \\
\text { preformed (HUVEC and gel) networks } \\
\text { with the circulatory system of SCD mice } \\
\text { (3) overexpression of Bcl-2 in HUVEC } \\
\text { resulted to the formation of perfused } \\
\text { vascular structures invested by mouse } \\
\text { pericyte and smooth-muscle cells that } \\
\text { remodel into mature vessels }\end{array}$ & $\begin{array}{l}\text { in vitro } \\
\text { in vivo in } \\
\text { severe } \\
\text { combined } \\
\text { immunodefi- } \\
\text { cient } \\
(\mathrm{SCID}) / \text { mice }\end{array}$ & {$[65]$} \\
\hline
\end{tabular}

(1) EPC-derived EC can be expanded in vitro and preserved endothelial

Polyglycolic

2004 acid-poly-L-lactic acid (PGA-PLLA) scaffolds
EPC from human umbilical cord were used to generate EPC-derived EC phenotype after seeding

(2) EPC-derived EC seeded with human smooth muscle cells form microvessels on porous PGA-PLLA scaffolds

(3) functional microvessels were evident 7-10 days after implantation into mice in vitro

nude mice in vivo in

[55]

(1) SMCs were uniformly distributed throughout EDC/NHS crosslinked collagen/elastin construct

in vitro

[68]

(2) collagen fibers were oriented to circumferential direction

\begin{tabular}{|c|c|c|c|c|c|}
\hline 2005 & $\begin{array}{l}\text { Sandwich chitosan } \\
\text { tubular scaffold }\end{array}$ & $\begin{array}{l}\text { Rabbit Smooth muscle } \\
\text { cells by employing } \\
\text { industrial knitting } \\
\text { process and } \\
\text { thermally-induced } \\
\text { phase-separation } \\
\text { techniques }\end{array}$ & $\begin{array}{l}\text { (1) chitosan scaffold showed proper swelling } \\
\text { property and high suture retention } \\
\text { (2) burst strength of the scaffold is } \\
4000 \mathrm{mmHg} \\
\text { (3) scaffold degraded after } 2 \text { months } \\
\text { (4) SMCs were well grown and distributed } \\
\text { in the scaffold }\end{array}$ & in vitro & [69] \\
\hline 2007 & $\begin{array}{l}\text { Poly(glycerol } \\
\text { sebacate) (PGS) films } \\
\text { and scaffolds }\end{array}$ & $\begin{array}{l}\text { Baboon endothelial } \\
\text { progenitor cells } \\
\text { (BaEPCs) and } \\
\text { baboon smooth } \\
\text { muscle cells (BaSMCs) }\end{array}$ & $\begin{array}{l}\text { (1) BaSMCs were distributed throughout } \\
\text { the scaffolds and synthesized ECM } \\
\text { (2) BaSMC-seeded constructs provided } \\
\text { suitable surfaces for BaEPC adhesion } \\
\text { (3) cells maintained their specific } \\
\text { phenotypes }\end{array}$ & in vitro & [70] \\
\hline 2008 & $\begin{array}{l}\text { PGA (polyglycolic } \\
\text { acid) fiber mesh }\end{array}$ & $\begin{array}{l}\text { SMC/pulsatile } \\
\text { stimulation from } \\
\text { a Bioreactor }\end{array}$ & $\begin{array}{l}\text { (1) elastic vessel wall was formed after } 8 \\
\text { weeks of dynamic engineering. } \\
\text { (2) histological examination showed } \\
\text { well-orientated smooth muscle cells and } \\
\text { collagenous fibers }\end{array}$ & in vitro & [71] \\
\hline
\end{tabular}


TABle 2: Continued.

\begin{tabular}{|c|c|c|c|c|c|}
\hline $\begin{array}{l}\text { Publication } \\
\text { year }\end{array}$ & Scaffold & Source/signal & Reported results & Type of study & References \\
\hline 2009 & $\begin{array}{l}\text { 3D collagen/fibro- } \\
\text { nectin gels } \\
\text { supported by } \\
\text { a nonwoven, } \\
\text { degradable PGA } \\
\text { (polyglycolic acid) } \\
\text { matrix }\end{array}$ & HUVECs, EC and SMC & $\begin{array}{l}\text { (1) after transplantation PGA-supported gels, } \\
\text { Bcl-2-HUVEC retained the ability to form } \\
\text { microvessels invested by mouse SMC. } \\
\text { (2) grafts containing both Bcl-2-HUVEC and } \\
\text { HASMC displayed greater numbers of smooth } \\
\text { muscle actinin expressing cells associated with } \\
\text { human EC-lined arteriole-like microvessels } \\
\text { (3) SMC can accelerate, stabilize, and promote } \\
\text { remodeling of tissue engineered microvessels } \\
\text { (4) EC-SMC coengraftment and cotransplantation } \\
\text { in PGA-supported protein gels may have } \\
\text { broader application for perfusing bioengineered } \\
\text { tissues }\end{array}$ & $\begin{array}{l}\text { in vitro } \\
\text { in vivo in } \\
\text { severe } \\
\text { combined } \\
\text { immune- } \\
\text { deficient } \\
\text { (SCID)/mice }\end{array}$ & {$[72]$} \\
\hline 2010 & $\begin{array}{l}\text { PGA (polyglycolic } \\
\text { acid) unwoven } \\
\text { mesh }\end{array}$ & $\begin{array}{l}\text { SMC derived from } \\
\text { hASCs/pulsatile } \\
\text { stimulation from } \\
\text { a Bioreactor, TGF- } \beta 1 \text {, } \\
\text { BMP-4 }\end{array}$ & $\begin{array}{l}\text { (1) hASCs acquired SMC phenotype with SMC- } \\
\text { related markers expression } \\
\text { (2) under pulsatile stimulation, hASCs can be } \\
\text { SMC cell source with biomechanical strength } \\
\text { matchable to the native vessels }\end{array}$ & in vitro & {$[42]$} \\
\hline 2012 & $\begin{array}{l}\text { Macroporous } \\
\text { nanofibrous } \\
\text { scaffold }\end{array}$ & $\begin{array}{l}\text { ESCs stimulated with } \\
\text { retinoic acid with LacZ } \\
\text { genetic labeling under } \\
\text { SMC alpha promoter }\end{array}$ & $\begin{array}{l}\text { (1) RA enhanced SMC gene expression while } \\
\text { inhibiting pluripotency of ESC } \\
\text { (2) implanted cells in mice maintained LacZ } \\
\text { staining within the construct without teratoma } \\
\text { formation } \\
\text { (3) ESC-promising source of SMC for therapeutic } \\
\text { vascular engineering and disease model } \\
\text { application }\end{array}$ & $\begin{array}{l}\text { in vitro } \\
\text { in vivo in } \\
\text { nude mice }\end{array}$ & {$[43]$} \\
\hline
\end{tabular}

Biotubular scaffold

composed of

polyglycolide

knitted fiber, and

2012 an L-lactide and

$\varepsilon$-caprolactone

copolymer sponge

crosslinked to

Amniotic Fluid

Amniotic Fluid

Tissue engineered (AM) as the natural

2012 blood vessel from amniotic

membrane
(1) well-formed vasculature without stenosis or thrombosis, and calcification

(2) cell-free vasculature with good quality and adaptation in shape

(3) applicable to pediatric surgery

(4) the use of Amniotic Fluid shortened EBV fabrication in vitro

in vivo in the

inferior vena

cava of

Canines
(1) shear stress application maintained the intact monolayer of EC in the vessel's lumen

(2) endothelial cells (ECs) are aligned in long axis parallel to the blood flow

(3) shear stress also increased PECAM-1 and

in vitro

E-cadherin and integrin $\alpha \gamma \beta 3$ expressions

(4) amniotic fluid tube reduced the TEBV fabrication through sheet-based engineering

Tubular hydrogels of circumferentially SMCs by applying low

2012 aligned peptide amphiphile shear stress and ionic crosslinking
(1) arterial cell scaffolds encapsulates and orient vascular cells

(2) direct cell organization without external in vitro stimulation or gel compaction biological properties and modifications of materials to further understand the molecular mechanism of the cellmaterial interaction [31]. The lack of endothelial cells on the luminal surface of the artificial grafts contributes to synthetic graft thrombogenicity and promotes intimal proliferation within the graft. Endothelial cell (EC) seeding on the synthetic grafts has been attempted to mitigate these problems. Herring et al. [87] were among the first to perform endothelial cell (EC) isolation and their subsequent transplantation into vascular graft. Current researches indicate the significance of such process in vascular tissue engineering. The polymer surfaces which have been formerly investigated for endothelial attachment, proliferation, and function had been listed in an earlier review [3]. On the other hand, the synthetic polymers for reconstructing blood vessels for clinical practice which are based on polyethylene 
TABLE 3: Representative studies on cell-based tissue-engineered blood vessels.

\begin{tabular}{|c|c|c|c|}
\hline $\begin{array}{l}\text { Publication } \\
\text { year }\end{array}$ & Construct & Source & Technique applied \\
\hline 1998 & $\begin{array}{l}\text { Completely } \\
\text { biological } \\
\text { tissue- } \\
\text { engineered } \\
\text { human blood } \\
\text { vessel }\end{array}$ & $\begin{array}{l}\text { SMCs, human } \\
\text { fibroblasts, } \\
\text { endothelial cells }\end{array}$ & $\begin{array}{l}\text { (i) cell culture in a } \\
\text { medium with } \\
\text { ascorbic acid } \\
\text { (ii) layered SMCs placed } \\
\text { in a tubular support } \\
\text { to form the media, } \\
\text { wrapped with a sheet } \\
\text { of fibroblasts to form } \\
\text { the adventitia } \\
\text { (iii) after maturation, } \\
\text { tubular support was } \\
\text { removed and } \\
\text { sequentially seeded } \\
\text { with endothelial cells } \\
\text { in the lumen to form } \\
\text { the intima }\end{array}$ \\
\hline
\end{tabular}

Tissueengineered 2000 blood vessel SMCs from smooth muscles (i) cell culture in a medium with serum and ascorbic acid

Reported results

Type of study References

(1) TEBV displayed well-defined three-layered organization, with numerous ECM proteins including elastin

(2) SMCs reexpressed desmin

(3) endothelium expressed von Willebrand factor, incorporated acetylated LDL, produced PGI, and inhibited platelet adhesion

(4) the grafting in canine model demonstrated good handling and saturability characteristics

$$
\begin{gathered}
\text { in vitro } \\
\text { in vivo } \\
\text { in canine } \\
\text { model }
\end{gathered}
$$

(1) TEBV composed of endothelium, media, and adventitia and resembling human artery was produced

(2) serum stimulates cell differentiation and growth and increases cell viability

(3) ascorbic acid induced cohesive cellular sheet organization (i) decellularization of porcine iliac vessels

Small-diameter neovessels

EPCs (ii) EPCs were isolated noninvasively from peripheral blood of sheep, expanded ex vivo
(1) endothelial progenitor cell-seeded grafts remained patent for 130 days

(2) nonseeded grafts occluded in vitro within 15 days.

(3) explanted grafts exhibited in sheep vascular contractile and model relaxation activity similar to native arteries

(1) vascular grafts seeded with BMCs remained patent for up to 8 weeks

(2) vascular grafts showed regeneration of the 3 vascular layers

in vivo in

(ii) decellularization of canine artery

(iii) transplantation of grafts in canine carotid artery

(3) the first autologous vessel derived from BMCs

(4) occlusion due to Thrombus formation was evident

(1) TEBV exhibited properties similar to human blood vessels, without exogenous scaffolding

(2) autologous TEBVs are antithrombogenic and mechanically stable for 8 months in vivo

canine model

(3) well-established vasa vasorum, vasa media, and intima

(4) the TEBV was manufactured exclusively from patient's own cells, completely biological and clinically relevant 
TABle 3: Continued.

\begin{tabular}{|c|c|c|c|}
\hline $\begin{array}{l}\text { Publication } \\
\text { year }\end{array}$ & Construct & Source & Technique applied \\
\hline 2009 & $\begin{array}{l}\text { Scaffold-free } \\
\text { small- } \\
\text { diameter } \\
\text { vascular } \\
\text { construct }\end{array}$ & $\begin{array}{l}\text { SMCs and } \\
\text { fibroblasts }\end{array}$ & $\begin{array}{l}\text { (i) bioprinting using } \\
\text { vascular smooth } \\
\text { muscle cells and } \\
\text { fibroblasts }\end{array}$ \\
\hline 2009 & $\begin{array}{l}\text { Scaffold-free } \\
\text { arterial } \\
\text { mimetics }\end{array}$ & $\begin{array}{l}\text { Human } \\
\text { aortic } \\
\text { Endothe- } \\
\text { lial cells } \\
\text { and } \\
\text { smooth } \\
\text { muscle } \\
\text { cells }\end{array}$ & $\begin{array}{l}\text { (i) ECs and SMCs were } \\
\text { co-cultured in } \\
\text { platform that mimic } \\
\text { either healthy or } \\
\text { diseased blood vessels } \\
\text { (ii) incorporation of } \\
\text { transforming growth } \\
\text { factor (TGF- } \beta \text { ) and } \\
\text { heparin in culture } \\
\text { media to upregulate } \\
\text { SMC differentiation } \\
\text { markers ( } \alpha \text {-SMA and } \\
\text { calponin) }\end{array}$ \\
\hline
\end{tabular}

\begin{tabular}{|c|c|}
\hline $\begin{array}{l}\text { Self- } \\
\text { assembled } \\
\text { microtissue } \\
\text { vessel } \\
\text { building } \\
\text { blocks }\end{array}$ & $\begin{array}{l}\text { Human } \\
\text { artery- } \\
\text { derived } \\
\text { fibroblasts } \\
\text { and } \\
\text { HUVECs }\end{array}$ \\
\hline
\end{tabular}

(i) pulsatile and circumferential mechanical stimulation in a bioreactor composed of pulsatile pump, self-assembly device, and medium reservoir

Reported results

Type of study References

(1) vascular cells which were aggregated into distinct units (spheroids and cylinders) were printed layer-by-layer and molded using agarose rods as templates

(2) engineered vessels were fabricated in vitro [80] with distinct shapes and hierarchical trees that combine tubes with distinct diameter

(3) quick and scalable technique

(1) seeding of near confluent ECs on the scaffold induced increased $\alpha$-smooth muscle actinin ( $\alpha$-SMA) and calponin Expression

(2) pretreatment of TGF- $\beta$ and heparin to SMC enhanced $\alpha$-SMA in vitro and calponin levels

(3) EC-SMC co-culture model can mimic either healthy or diseased blood vessels and may be useful in cardio-vascular therapeutics

(1) significant ECM formation and maturation by the self-assembled microtissues

(2) microtissues displayed prevascularization capacity and can be used as building blocks in generating small TEBV

(3) accumulation of vessel-like tissues occurred within 14 days under static and flow stimulation

(4) no thrombosis and vessel occlusions

(i) fibroblasts seeding on fibrin gel

(ii) direct injection of cell/fibrinogen suspension into glass mandrel tubular molds

Implantable Human

2011 human dermal

(iii) two weeks static culture system arterial grafts fibroblasts

(iv) nine weeks multigraft pulsed flow-stretch culture system in a bioreactor

(v) noninvasive strength monitoring

SmallMarrowdiameter

tissuederived engineered mal stem vascular graft cells
(TEVG)
(MSCs)

(i) cell sheet engineering

(ii) cell sheeting rolling around a mandrel

(iii) graft transplantation
(1) cells cultured in pulsed-flow bioreactor produced more collagen and with higher burst pressures

(2) the tissue suture retention force was suitable for implantation in rat and ovine model model and in ovine model using poly(lactic acid) sewing rings

(1) adhesion assay revealed that MSCs share similar EC's antiplatelet adhesion property

(2) cell sheet layers fully fused in vitro

(3) four weeks after transplantation, in vivo in rabbit and similar structure of native vessels model

(4) the fabricated biological TEVGs are useful for revascularization in humans and may reduce complication with foreign materials 
terephthalate (PET) or polytetrafluoroethylene (PTFE) had been previously reviewed [31]. Furthermore, blood vessel stem cells have been studied in combination with recent and alternative types of scaffolds/polymers. Parallel to this, in scaffold-based blood vessel engineering, bioreactors and pulsatile flow systems, designed by many scientists, have been found to progress the mechanical property of the engineered blood vessels by augmenting the deposition and remodeling of extracellular matrix as well as the maturation and differentiation of self-assembled microtissues [38, 39, $67,68,76]$. Bioreactors, which were originally designed for industrial use, have high degree of reproducibility, control, and automation for specific experimental bioprocesses and these have been the reasons for their transfer to largescale applications including vascular tissue engineering. The bioreactors allow scientists to manipulate the environment and the parameters such as $\mathrm{pH}$, temperature, pressure, nutrient supply, and waste removal in order mimic the in vivo physiological condition and allow biological or biochemical processes to occur and subsequently develop the desired tissue [88].

Taken together, the formation of a microvasculature within a tissue-engineered organ or tissue will depend on multiple factors: the biochemical environment, EC type, the micro-architecture presented by the scaffold material, and mechanical signals $[89,90]$. Due to the goal of developing biomimetic blood vessel scaffolds, many groups have designed such biomaterials. The representative studies on the different blood vessel scaffolds are depicted in Table 2. The polymers used in scaffold fabrication for tissue engineered blood vessels started from polyglycolic (PGA) to varied types such as polyglycolic acid-poly-L-lactic acid (PGAPLLA), Collagen/Elastin, chitosan, Poly (glycerol sebacate) (PGS), and very recently polyglycolide knitted fiber, and an L-lactide and $\mathcal{E}$-caprolactone copolymer sponge crosslinked to amniotic fluid. Furthermore, amniotic membranes have been used as scaffolds which signify that scaffoldbased tissue-engineered blood vessels can be fabricated from autologous cells at a reduced manufacturing period.

\section{Scaffold-Free Techniques for Blood Vessels}

The chronic inflammation, thrombosis, rejection, and poor mechanical properties of allogeneic or xenogeneic and synthetic vessels have impaired their clinical applications [79]. In addition, due to the failure cell to cell interaction and the assembly and alignment of ECM components, and the complex host response to scaffolds, the scaffoldfree techniques had recently emerged [80]. In scaffold-free tissue engineering approach, the fabrication of the tissue construct is anchored in the crucial capability of the cells to manufacture their own extracellular matrix [39]. In 1998, the first scaffold-free tissue-engineered human blood vessel was established by L' Heureux and has been replicated for further preclinical evaluation using rat and mice models in 2006 [76, 79]. Years later, groups of scientists reported a fully biological self-assembly approaches by implementing rapid prototyping bioprinting method and stimulation via bioreactors for scaffold-free small diameter vascular reconstruction $[39,80]$.

Similar to scaffold-based technique, in tissue engineering for scaffold-free blood vessels, the bioreactors were also used to provide specific biochemical and physical signals to regulate cell differentiation, ECM production, and tissue assembly by using chemical, mechanical, or electromagnetic stimulation techniques to produce de novo tissue with properties comparable to the damaged or desired tissues $[91,92]$. There are many types of launched bioreactors however, in engineering the vascular tissues, designs of various bioreactors have been based on the expansion and recoil properties of blood vessels, and so the combinations of stress, strain, and perfusion stimulation in biomimetic bioreactors have successfully developed vascular tissues [92].

In case of cell senescence problem, lifespan extension via telomerase expression in vascular cells (smooth muscle cells and endothelial cells) from elderly patients has been found as an effective strategy for engineering autologous blood vessels and eventually provides bypass conduit for atherosclerotic diseases [38]. Human telomerase, composed of an RNA component and a reverse transcriptase (hTERT), maintains the telomere length at the ends of the chromosomes [93]. Absence of hTERT expression in mature somatic cells induces lack of telomerase activity thus its ectopic expression has been shown to restore telomerase activity, arrest telomere shortening and senescence in some cells [94]. While high cell population is essential in cell-based vessel biofabrication and the expansion process is lengthy, cell-based therapies are more promising in terms of efficacy despite the fact that they are more complex and costly than scaffold-based techniques [7]. Therefore, many researches have focused on this approach and the representative studies are presented in Table 3. Among the well-studied scaffold-free techniques are the coculture system, sheet-based engineering, decellularization, direct cell injection, bioprinting, and biofabrication in a bioreactor system.

\section{Conclusion and Future Directions}

At present, the previously established treatments for cardiovascular disorders, such as organ transplantation, surgical reconstruction, usage of mechanical and synthetic devices, or administration of metabolic products, although promising are still yet constraints and complication-free [3]. Hence, the developments in vitro and in vivo generation of biomimetic constructs for specific target organ or tissue are more suitable for regeneration of damaged cardiovascular organs [95]. Albeit the points of view of Demirbag et al. [12] on the benefits and drawbacks of the applications scaffold and scaffold-free approaches over each other are indeed noteworthy. Due to the uniqueness of cells, tissues, and nature of cardiovascular defects, these approaches should be considered complementary instead of being competing components of vascular tissue engineering [12]. The treatment for blood vessel defects (Figure 4) would always depend on the pathological condition of the patient. If the patient has no limitations for transplantation, then autologous blood 


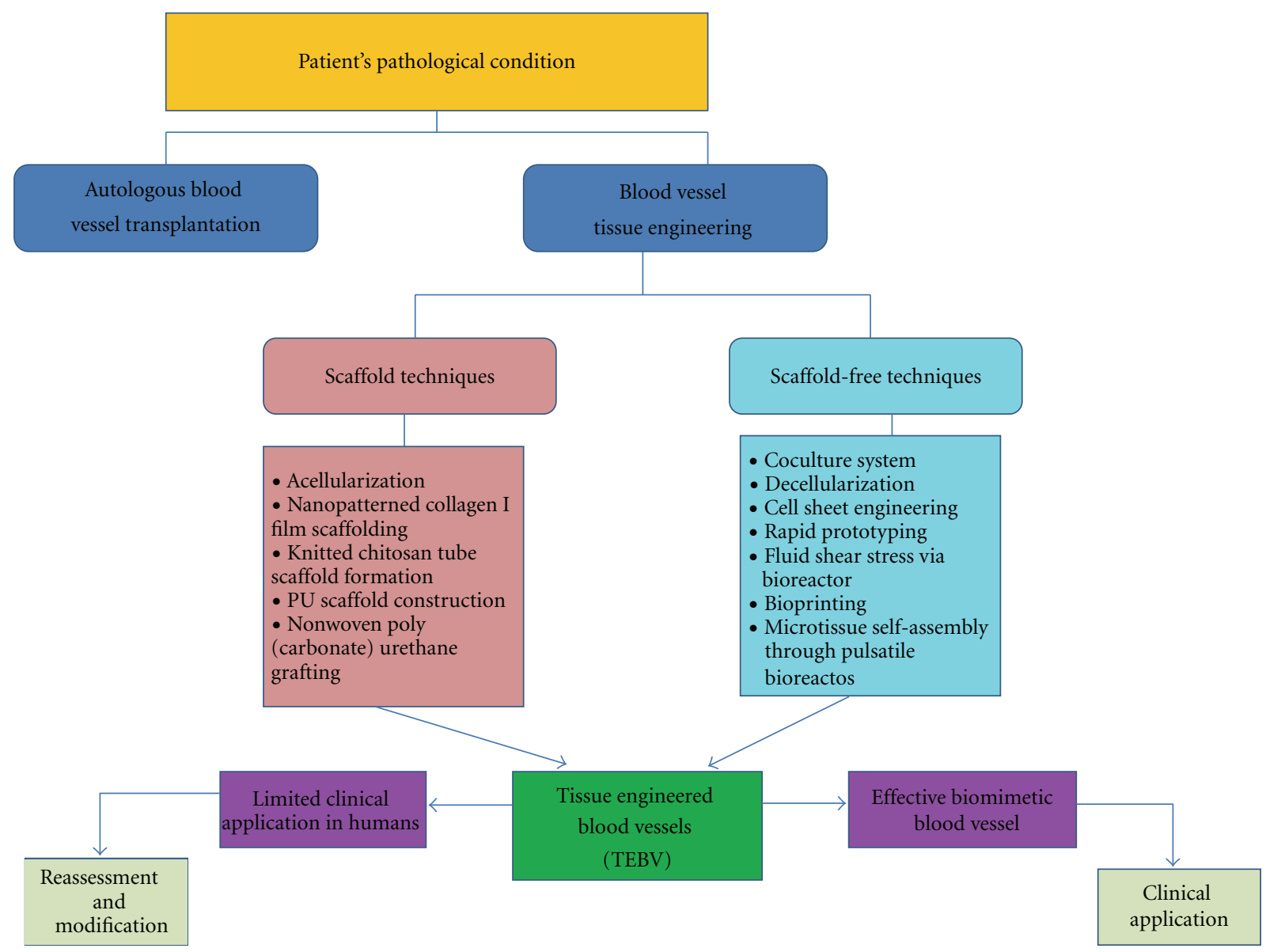

FIGURE 4: Trends in blood vessel tissue engineering.The patient's condition is the main basis for treatment of blood vessel defects. Autologous blood vessel transplantation is still the standard treatment. Conversely, tissue-engineered blood vessels (TEBV), fabricated either via scaffold or scaffold-free techniques, are the alternative sources of treatment.

vessels may be directly utilized for treatment. Otherwise, especially in the cases congenital defects, tissue-engineered blood vessels manufactured, either scaffold based or cell based, may be considered as the alternative treatment. The current blood vessel constructs still have their corresponding limitations, therefore, further reassessment and modification have to be conducted. However, once a biomimetic blood vessel is produced, then transplantation can be the convenient treatment for blood vessel defects most especially in the infants whose transplantable large blood vessels are not yet ready for harvest.

In the future, further combination of techniques may be considered in the production and design of cardiovascularengineered tissues for the blood vessels. For instance, the High-Density Suspension System (HDSS) initiated by Lee et al. [96] for constructing spherical spheroids composed of cartilage and synovium cells was found to be an effective and efficient culture system, then the spheroids were successfully implanted and able to heal the bone defects of the knee in rabbit model. Such technique may be applied for expanding stem cells for the cardiovascular diseases especially if the construct has to be composed of a mixture of cells such as myofibroblast, smooth muscles,
EPCs, and many others for blood vessel defects. Hence, this strategy may enhance the existing coculture system applied in the construction of engineered blood vessels. However, it would be better if researchers will be able to design a completely scaffold-free product since it is more beneficial in a sense that complications can be prevented and might promote greater life expectancy of the individuals affected with vascular diseases. It will remain a challenge to devise blood vessel engineered tissue until completely biomimetic construct is produced. Furthermore, since angiogenesis is essential in almost all types of organ remodeling and tissue engineering, it is indeed a crucial step for the complex organ reconstruction [77]. Hence, it is also interesting to explore the importance and the interrelationships of the vascularization signaling pathways in designing biomaterials. Perhaps, along the process of biofabrication, certain growth factors and other signaling molecules may be incorporated while regulating their release into the scaffold or scaffold-free construct in order to enhance blood vessel reconstruction on the injured site. The designs of the bioreactors may be further improved to hasten vascular tissue construction through their efficient and effective stimulation and by combining them with automated cell tissue culture systems 
to reduce time-consuming expansion period which primarily delimit the clinical application of the current vascular grafts especially in cases of emergencies. This may be the future mechanism in vascular tissue engineering.

\section{Authors' Contribution}

J. G. Nemeno-Guanzon and S. Lee equally contributed to this paper and should be considered cofirst authors. The rest of the authors have no conflict of interests to declare.

\section{Acknowledgment}

This research was supported by Basic Science Research Program through the National Research Foundation of Korea (NRF) funded by the Ministry of Education, Science and Technology (2010-0024188).

\section{References}

[1] V. L. Roger, A. S. Go, D. M. Lloyd-Jones et al., "Heart disease and stroke statistics-2011 update: a report from the American Heart Association," Circulation, vol. 125, no. 1, pp. e2-e220, 2012.

[2] C. Zaragoza, C. Gomez-Guerrero, J. L. Martin-Ventura et al., "Animal models of cardiovascular diseases," Journal of Biomedicine and Biotechnology, vol. 2011, Article ID 497841, 2011.

[3] H. M. Nugent and E. R. Edelman, "Tissue engineering therapy for cardiovascular disease," Circulation Research, vol. 92, no. 10, pp. 1068-1078, 2003.

[4] J. L. Platt, "Preface: future approaches to replacement of organs," American Journal of Transplantation, vol. 4, no. 6, pp. 5-6, 2004.

[5] B. Ogle, M. Cascalho, and J. L. Platt, "Fusion of approaches to the treatment of organ failure," American Journal of Transplantation, vol. 4, supplement 6, pp. 74-77, 2004.

[6] J. Yang, M. Yamato, C. Kohno et al., "Cell sheet engineering: recreating tissues without biodegradable scaffolds," Biomaterials, vol. 26, no. 33, pp. 6415-6422, 2005.

[7] N. L'Heureux, N. Dusserre, A. Marini, S. Garrido, L. de la Fuente, and T. McAllister, "Technology insight: the evolution of tissue-engineered vascular grafts-from research to clinical practice," Nature Clinical Practice Cardiovascular Medicine, vol. 4, no. 7, pp. 389-395, 2007.

[8] J. R. Porter, T. T. Ruckh, and K. C. Popat, "Bone tissue engineering: a review in bone biomimetics and drug delivery strategies," Biotechnology Progress, vol. 25, no. 6, pp. 15391560, 2009.

[9] W. Ji, Y. Sun, F. Yang et al., "Bioactive electrospun scaffolds delivering growth factors and genes for tissue engineering applications," Pharmaceutical Research, vol. 28, no. 6, pp. 1259-1272, 2011.

[10] J. P. Vacanti and R. Langer, "Tissue engineering: the design and fabrication of living replacement devices for surgical reconstruction and transplantation," The Lancet, vol. 354, supplement 1, pp. S32-S34, 1999.

[11] B. S. Kim and D. J. Mooney, "Development of biocompatible synthetic extracellular matrices for tissue engineering," Trends in Biotechnology, vol. 16, no. 5, pp. 224-230, 1998.
[12] B. Demirbag, P. Y. Huri, G. T. Kose, A. Buyuksungur, and V. Hasirci, "Advanced cell therapies with and without scaffolds," Biotechnology Journal, vol. 6, no. 12, pp. 1437-1453, 2011.

[13] T. C. Flanagan and A. Pandit, "Living artificial heart valve alternatives: a review," European Cells and Materials, vol. 6, pp. 28-45, 2003.

[14] R. Langer and J. P. Vacanti, “Tissue engineering," Science, vol. 260, no. 5110, pp. 920-926, 1993.

[15] M. D. Rosenberg, "Cell guidance by alterations in monomolecular films," Science, vol. 139, no. 3553, pp. 411-412, 1963.

[16] Z. Ma, M. Kotaki, R. Inai, and S. Ramakrishna, "Potential of nanofiber matrix as tissue-engineering scaffolds," Tissue Engineering, vol. 11, no. 1-2, pp. 101-109, 2005.

[17] J. W. Nichol and A. Khademhosseini, "Modular tissue engineering: engineering biological tissues from the bottom up," Soft Matter, vol. 5, no. 7, pp. 1312-1319, 2009.

[18] S. Ravi and E. L. Chaikof, "Biomaterials for vascular tissue engineering," Regenerative Medicine, vol. 5, no. 1, pp. 107-120, 2010.

[19] S. C. Rizzi, M. Ehrbar, S. Halstenberg et al., "Recombinant protein-co-PEG networks as cell-adhesive and proteolytically degradable hydrogel matrixes. Part II: biofunctional characteristics," Biomacromolecules, vol. 7, no. 11, pp. 3019-3029, 2006.

[20] N. Grabow, K. Schmohl, A. Khosravi et al., "Mechanical and structural properties of a novel hybrid heart valve scaffold for tissue engineering," Artificial Organs, vol. 28, no. 11, pp. 971979, 2004.

[21] D. S. Vara, H. J. Salacinski, R. Y. Kannan, L. Bordenave, G. Hamilton, and A. M. Seifalian, "Cardiovascular tissue engineering: state of the art," Pathologie Biologie, vol. 53, no. 10, pp. 599-612, 2005.

[22] K. Berger, L. R. Sauvage, A. M. Rao, and S. J. Wood, "Healing of arterial prostheses in man: its incompleteness," Annals of Surgery, vol. 175, no. 1, pp. 118-127, 1972.

[23] R. F. Furchgott and J. V. Zawadzki, "The obligatory role of endothelial cells in the relaxation of arterial smooth muscle by acetylcholine," Nature, vol. 288, no. 5789, pp. 373-376, 1980.

[24] I. Autio, U. Malo-Ranta, O. P. Kallioniemi, and T. Nikkari, "Cultured bovine aortic endothelial cells secrete factor(s) chemotactic for aortic smooth muscle cells," Artery, vol. 16, no. 2, pp. 72-83, 1989.

[25] M. I. Cybulsky and M. A. Gimbrone Jr., "Endothelial expression of a mononuclear leukocyte adhesion molecule during atherogenesis," Science, vol. 251, no. 4995, pp. 788-791, 1991.

[26] W. Casscells, "Migration of smooth muscle and endothelial cells: critical events in restenosis," Circulation, vol. 86, no. 3, pp. 723-729, 1992.

[27] M. W. Majesky, X. R. Dong, V. Hoglund, W. M. Mahoney Jr., and G. Daum, "The adventitia: a dynamic interface containing resident progenitor cells," Arteriosclerosis, Thrombosis, and Vascular Biology, vol. 31, no. 7, pp. 1530-1539, 2011.

[28] C.-W. Chen, M. Corselli, B. Péault, and J. Huard, "Human blood-vessel-derived stem cells for tissue repair and regeneration," Journal of Biomedicine and Biotechnology, vol. 2012, Article ID 597439, 9 pages, 2012.

[29] Y. Y. Chen, C. W. Liu, W. Ye, R. Zhang, Y. S. Wei, and D. P. Liu, "Effects of Batroxobin on distal anastomotic intimal hyperplasia after expanded polytetrafluoroethylene bypass grafting in dog common carotid artery," Zhonghua Yi Xue Za Zhi, vol. 89, no. 1, pp. 48-53, 2009.

[30] J. N. Wilcox and N. A. Scott, "Potential role of the adventitia in arteritis and atherosclerosis," International Journal of Cardiology, vol. 54, supplement, pp. S21-S35, 1996. 
[31] M. Parizek, K. Novotna, and L. Bacakova, "The role of smooth muscle cells in vessel wall pathophysiology and reconstruction using bioactive synthetic polymers," Physiological Research, vol. 60, no. 3, pp. 419-437, 2011.

[32] R. Ross, "The pathogenesis of atherosclerosis: a perspective for the 1990s," Nature, vol. 362, no. 6423, pp. 801-809, 1993.

[33] M. Moriyama, S. Kubota, H. Tashiro, and H. Tonami, "Evaluation of prosthetic venous valves, fabricated by electrospinning, for percutaneous treatment of chronic venous insufficiency," Journal of Artificial Organs, vol. 14, no. 4, pp. 294-300, 2011.

[34] P. Klinkert, P. N. Post, P. J. Breslau, and J. H. van Bockel, "Saphenous vein versus PTFE for above-knee femoropopliteal bypass. A review of the literature," European Journal of Vascular and Endovascular Surgery, vol. 27, no. 4, pp. 357-362, 2004.

[35] E. D. Foster and M. A. T. Kranc, "Alternative conduits for aortocoronary bypass grafting," Circulation, vol. 79, no. 6, part 2, pp. I34-I39, 1989.

[36] B. C. Isenberg, C. Williams, and R. T. Tranquillo, "Smalldiameter artificial arteries engineered in vitro," Circulation Research, vol. 98, no. 1, pp. 25-35, 2006.

[37] M. S. Conte, "The ideal small arterial substitute: a search for the Holy Grail?” The FASEB Journal, vol. 12, no. 1, pp. 43-45, 1998.

[38] M. Poh, M. Boyer, A. Solan et al., "Blood vessels engineered from human cells," The Lancet, vol. 365, no. 9477, pp. 21222124, 2005.

[39] J. M. Kelm, V. Lorber, J. G. Snedeker et al., "A novel concept for scaffold-free vessel tissue engineering: self-assembly of microtissue building blocks," Journal of Biotechnology, vol. 148, no. 1, pp. 46-55, 2010.

[40] R. M. Nerem and A. E. Ensley, "The tissue engineering of blood vessels and the heart," American Journal of Transplantation, vol. 4, supplement 6, pp. 36-42, 2004.

[41] C. B. Weinberg and E. Bell, "A blood vessel model constructed from collagen and cultured vascular cells," Science, vol. 231, no. 4736, pp. 397-400, 1986.

[42] C. Wang, L. Cen, S. Yin et al., "A small diameter elastic blood vessel wall prepared under pulsatile conditions from polyglycolic acid mesh and smooth muscle cells differentiated from adipose-derived stem cells," Biomaterials, vol. 31, no. 4, pp. 621-630, 2010.

[43] J. Hu, C. Xie, H. Ma, B. Yang, P. X. Ma, and Y. E. Chen, "Construction of vascular tissues with macro-porous nanofibrous scaffolds and smooth muscle cells enriched from differentiated embryonic stem cells," PLoS One, vol. 7, no. 4, Article ID e35580, 2012.

[44] F. P. Barry and J. M. Murphy, "Mesenchymal stem cells: clinical applications and biological characterization," International Journal of Biochemistry and Cell Biology, vol. 36, no. 4, pp. 568584, 2004.

[45] P. A. Zuk, M. Zhu, H. Mizuno et al., "Multilineage cells from human adipose tissue: implications for cell-based therapies," Tissue Engineering, vol. 7, no. 2, pp. 211-228, 2001.

[46] K. Weinzierl, A. Hemprich, and B. Frerich, "Bone engineering with adipose tisssue derived stromal cells," Journal of CranioMaxillofacial Surgery, vol. 34, no. 8, pp. 466-471, 2006.

[47] Y. Zhu, T. Liu, K. Song, X. Fan, X. Ma, and Z. Cui, "Adiposederived stem cell: a better stem cell than BMSC," Cell Biochemistry and Function, vol. 26, no. 6, pp. 664-675, 2008.

[48] S. H. Bhang, S. W. Cho, J. M. Lim et al., "Locally delivered growth factor enhances the angiogenic efficacy of adiposederived stromal cells transplanted to ischemic limbs," Stem Cells, vol. 27, no. 8, pp. 1976-1986, 2009.
[49] K. Rubina, N. Kalinina, A. Efimenko et al., "Adipose stromal cells stimulate angiogenesis via promoting progenitor cell differentiation, secretion of angiogenic factors, and enhancing vessel maturation," Tissue Engineering A, vol. 15, no. 8, pp. 2039-2050, 2009.

[50] T. J. Lee, S. H. Bhang, H. S. Yang et al., "Enhancement of longterm angiogenic efficacy of adipose stem cells by delivery of FGF2," Microvascular Research, vol. 84, no. 1, pp. 1-8, 2012.

[51] A. Sterodimas, J. de Faria, B. Nicaretta, and I. Pitanguy, “Tissue engineering with adipose-derived stem cells (ADSCs): current and future applications," Journal of Plastic, Reconstructive and Aesthetic Surgery, vol. 63, no. 11, pp. 1886-1892, 2010.

[52] S. Levenberg, J. S. Golub, M. Amit, J. Itskovitz-Eldor, and R. Langer, "Endothelial cells derived from human embryonic stem cells," Proceedings of the National Academy of Sciences of the United States of America, vol. 99, no. 7, pp. 4391-4396, 2002.

[53] M. Hristov, W. Erl, and P. C. Weber, "Endothelial progenitor cells: mobilization, differentiation, and homing," Arteriosclerosis, Thrombosis, and Vascular Biology, vol. 23, no. 7, pp. 11851189, 2003.

[54] M. T. Hinds, M. Ma, N. Tran et al., "Potential of baboon endothelial progenitor cells for tissue engineered vascular grafts," Journal of Biomedical Materials Research A, vol. 86, no. 3, pp. 804-812, 2008.

[55] X. Wu, E. Rabkin-Aikawa, K. J. Guleserian et al., "Tissueengineered microvessels on three-dimensional biodegradable scaffolds using human endothelial progenitor cells," American Journal of Physiology, vol. 287, no. 2, pp. H480-H487, 2004.

[56] J. M. Hill, G. Zalos, J. P. J. Halcox et al., "Circulating endothelial progenitor cells, vascular function, and cardiovascular risk," The New England Journal of Medicine, vol. 348, no. 7, pp. 593-600, 2003.

[57] A. Kawamoto, T. Asahara, and D. W. Losordo, "Transplantation of endothelial progenitor cells for therapeutic neovascularization," Cardiovascular Radiation Medicine, vol. 3, no. 3-4, pp. 221-225, 2002.

[58] T. Shirota, H. He, H. Yasui, and T. Matsuda, "Human endothelial progenitor cell-seeded hybrid graft: proliferative and antithrombogenic potentials in vitro and fabrication processing," Tissue Engineering, vol. 9, no. 1, pp. 127-136, 2003.

[59] S. Kaushal, G. E. Amiel, K. J. Guleserian et al., "Functional small-diameter neovessels created using endothelial progenitor cells expanded ex vivo," Nature Medicine, vol. 7, no. 9, pp. 1035-1040, 2001.

[60] A. A. Kocher, M. D. Schuster, M. J. Szabolcs et al., "Neovascularization of ischemic myocardium by human bone-marrowderived angioblasts prevents cardiomyocyte apoptosis, reduces remodeling and improves cardiac function," Nature Medicine, vol. 7, no. 4, pp. 430-436, 2001.

[61] B. Assmus, V. Schächinger, C. Teupe et al., "Transplantation of progenitor cells and regeneration enhancement in acute myocardial infarction (TOPCARE-AMI)," Circulation, vol. 106, no. 24, pp. 3009-3017, 2002.

[62] M. Pesce, A. Orlandi, M. G. Iachininoto et al., "Myoendothelial differentiation of human umbilical cord blood-derived stem cells in ischemic limb tissues," Circulation Research, vol. 93, no. 5, pp. e51-e62, 2003.

[63] S. W. Cho, S. H. Lim, I. K. Kim et al., "Small-diameter blood vessels engineered with bone marrow-derived cells," Annals of Surgery, vol. 241, no. 3, pp. 506-515, 2005. 
[64] Y. S. Yoon, J. S. Park, T. Tkebuchava, C. Luedeman, and D. W. Losordo, "Unexpected severe calcification after transplantation of bone marrow cells in acute myocardial infarction," Circulation, vol. 109, no. 25, pp. 3154-3157, 2004.

[65] J. S. Schechner, A. K. Nath, L. Zheng et al., "In vivo formation of complex microvessels lined by human endothelial cells in an immunodeficient mouse," Proceedings of the National Academy of Sciences of the United States of America, vol. 97, no. 16, pp. 9191-9196, 2000.

[66] S. E. Hughes, "Functional characterization of the spontaneously transformed human umbilical vein endothelial cell line ECV304: use in an in vitro model of angiogenesis," Experimental Cell Research, vol. 225, no. 1, pp. 171-185, 1996.

[67] L. E. Niklason, J. Gao, W. M. Abbott et al., "Functional arteries grown in vitro," Science, vol. 284, no. 5413, pp. 489-493, 1999.

[68] L. Buttafoco, P. Engbers-Buijtenhuijs, A. A. Poot, P. J. Dijkstra, I. Vermes, and J. Feijen, "Physical characterization of vascular grafts cultured in a bioreactor," Biomaterials, vol. 27, no. 11, pp. 2380-2389, 2006.

[69] L. Zhang, Q. Ao, A. Wang et al., "A sandwich tubular scaffold derived from chitosan for blood vessel tissue engineering," Journal of Biomedical Materials Research A, vol. 77, no. 2, pp. 277-284, 2006.

[70] J. Gao, A. E. Ensley, R. M. Nerem, and Y. Wang, "Poly(glycerol sebacate) supports the proliferation and phenotypic protein expression of primary baboon vascular cells," Journal of Biomedical Materials Research A, vol. 83, no. 4, pp. 1070-1075, 2007.

[71] Z. C. Xu, W. J. Zhang, H. Li et al., "Engineering of an elastic large muscular vessel wall with pulsatile stimulation in bioreactor," Biomaterials, vol. 29, no. 10, pp. 1464-1472, 2008.

[72] B. R. Shepherd, S. M. Jay, W. M. Saltzman, G. Tellides, and J. S. Pober, "Human aortic smooth muscle cells promote arteriole formation by coengrafted endothelial cells," Tissue Engineering $A$, vol. 15, no. 1, pp. 165-173, 2009.

[73] G. Matsumura, N. Nitta, S. Matsuda et al., "Long-term results of cell-free biodegradable scaffolds for in situ tissueengineering vasculature: in a canine inferior vena cava model," PLoS One, vol. 7, no. 4, Article ID e35760, 2012.

[74] P.-H. Lee, S.-H. Tsai, L. Kuo et al., "A prototype tissue engineered blood vessel using amniotic membrane as scaffold," Acta Biomaterialia, vol. 8, no. 9, pp. 3342-3348, 2012.

[75] M. T. McClendon and S. I. Stupp, "Tubular hydrogels of circumferentially aligned nanofibers to encapsulate and orient vascular cells," Biomaterials, vol. 33, no. 23, pp. 5713-5722, 2012.

[76] N. L'Heureux, S. Pâquet, R. Labbé, L. Germain, and F. A. Auger, "A completely biological tissue-engineered human blood vessel," The FASEB Journal, vol. 12, no. 1, pp. 47-56, 1998.

[77] L. Germain, M. Remy-Zolghadri, and F. Auger, "Tissue engineering of the vascular system: from capillaries to larger blood vessels," Medical and Biological Engineering and Computing, vol. 38, no. 2, pp. 232-240, 2000.

[78] H. Ozaki and H. Karaki, "Organ culture as a useful method for studying the biology of blood vessels and other smooth muscle tissues," Japanese Journal of Pharmacology, vol. 89, no. 2, pp. 93-100, 2002.

[79] N. L'Heureux, N. Dusserre, G. Konig et al., "Human tissueengineered blood vessels for adult arterial revascularization," Nature Medicine, vol. 12, no. 3, pp. 361-365, 2006.

[80] C. Norotte, F. S. Marga, L. E. Niklason, and G. Forgacs, "Scaffold-free vascular tissue engineering using bioprinting," Biomaterials, vol. 30, no. 30, pp. 5910-5917, 2009.
[81] S. Chaterji, K. Park, and A. Panitch, "Scaffold-free in vitro arterial mimetics: the importance of smooth muscle-endothelium contact," Tissue Engineering A, vol. 16, no. 6, pp. 19011912, 2010.

[82] Z. H. Syedain, L. A. Meier, J. W. Bjork, A. Lee, and R. T. Tranquillo, "Implantable arterial grafts from human fibroblasts and fibrin using a multi-graft pulsed flow-stretch bioreactor with noninvasive strength monitoring," Biomaterials, vol. 32, no. 3, pp. 714-722, 2011.

[83] J. Zhao, L. Liu, J. Wei et al., "A novel strategy to engineer smalldiameter vascular grafts from marrow-derived mesenchymal stem cells," Artificial Organs, vol. 36, no. 1, pp. 93-101, 2012.

[84] L. Bacakova, E. Filova, F. Rypacek, V. Svorcik, and V. Stary, "Cell adhesion on artificial materials for tissue engineering," Physiological Research, vol. 53, supplement 1, pp. S35-S45, 2004.

[85] L. Bacakova, E. Filova, D. Kubies et al., "Adhesion and growth of vascular smooth muscle cells in cultures on bioactive RGD peptide-carrying polylactides," Journal of Materials Science, vol. 18, no. 7, pp. 1317-1323, 2007.

[86] L. Bacakova, "Cell colonization control by physical and chemical modification of materials," in Cell Growth Processes: New Research, D. Kimura, Ed., pp. 5-56, Nova Science, Huntington, NY, USA, 2008.

[87] M. Herring, A. Gardner, and J. Glover, "A single staged technique for seeding vascular grafts with autogenous endothelium," Surgery, vol. 84, no. 4, pp. 498-504, 1978.

[88] I. Martin, D. Wendt, and M. Heberer, "The role of bioreactors in tissue engineering," Trends in Biotechnology, vol. 22, no. 2, pp. 80-86, 2004.

[89] J. H. Brauker, V. E. Carr-Brendel, L. A. Martinson, J. Crudele, W. D. Johnston, and R. C. Johnson, "Neovascularization of synthetic membranes directed by membrane microarchitecture," Journal of Biomedical Materials Research, vol. 29, no. 12, pp. 1517-1524, 1995.

[90] M. C. Peters, P. J. Polverini, and D. J. Mooney, "Engineering vascular networks in porous polymer matrices," Journal of Biomedical Materials Research, vol. 60, no. 4, pp. 668-678, 2002.

[91] E. Oragui, M. Nannaparaju, and W. S. Khan, "The role of bioreactors in tissue engineering for musculoskeletal applications," The Open Orthopaedics Journal, vol. 5, supplement 2, pp. 267-270, 2011.

[92] N. Plunkett and F. J. O'Brien, "IV.3. bioreactors in tissue engineering," Studies in Health Technology and Informatics, vol. 152, pp. 214-230, 2010.

[93] T. M. Nakamura, G. B. Morin, K. B. Chapman et al., "Telomerase catalytic subunit homologs from fission yeast and human," Science, vol. 277, no. 5328, pp. 955-959, 1997.

[94] X. R. Jiang, G. Jimenez, E. Chang et al., "Telomerase expression in human somatic cells does not induce changes associated with a transformed phenotype," Nature Genetics, vol. 21, no. 1, pp. 111-1114, 1999.

[95] A. Simionescu, J. B. Schulte, G. Fercana, and D. T. Simionescu, "Inflammation in cardiovascular tissue engineering: the challenge to a promise: a minireview," International Journal of Inflammation, vol. 2011, Article ID 958247, 11 pages, 2011.

[96] J. I. Lee, M. Sato, H. W. Kim, and J. Mochida, “Transplantatation of scaffold-free spheroids composed of synovium-derived cells and chondrocytes for the treatment of cartilage defects of the knee," European Cells and Materials Journal, vol. 22, pp. 275-290, 2011. 


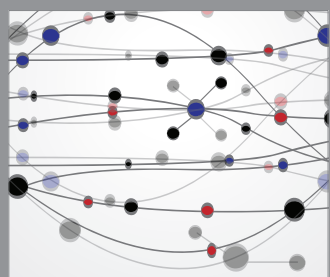

The Scientific World Journal
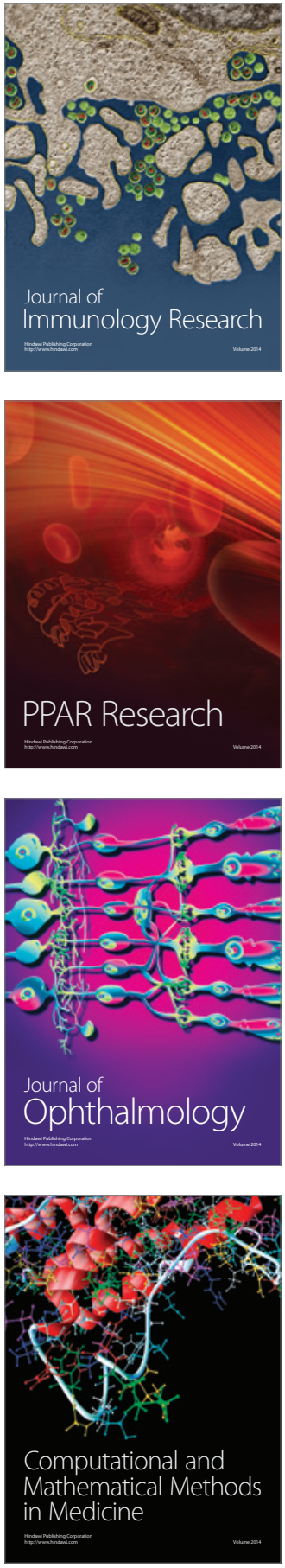

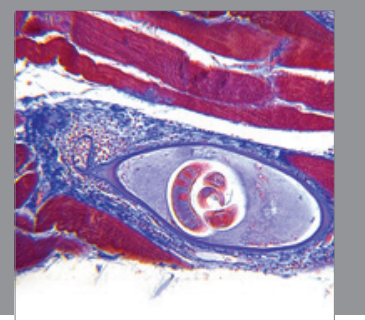

Gastroenterology

Research and Practice
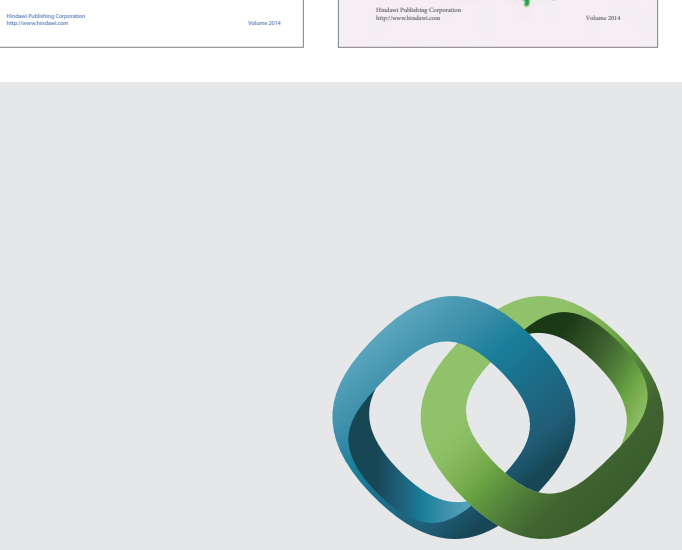

\section{Hindawi}

Submit your manuscripts at

http://www.hindawi.com
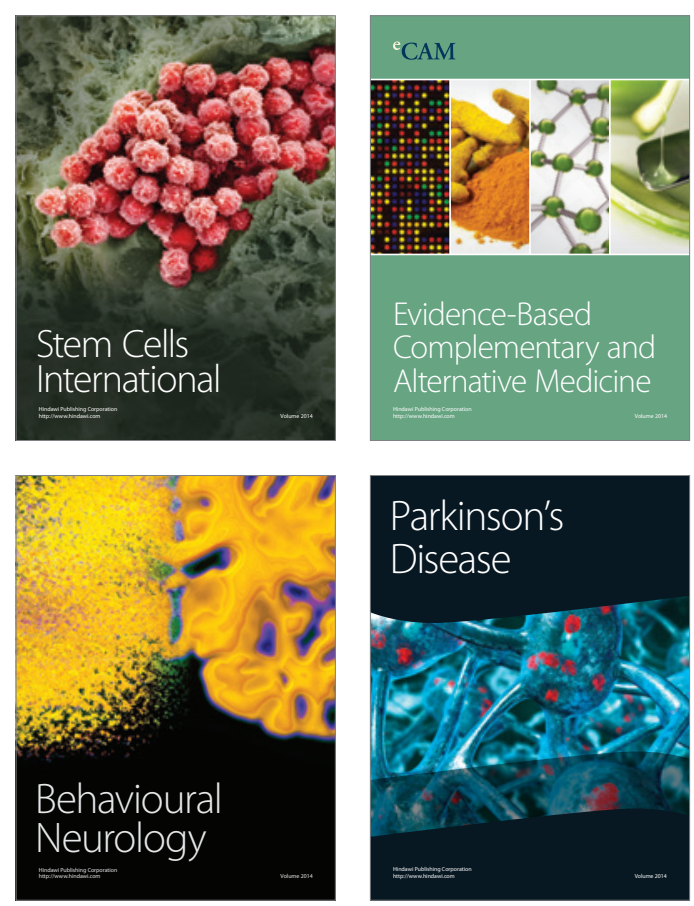

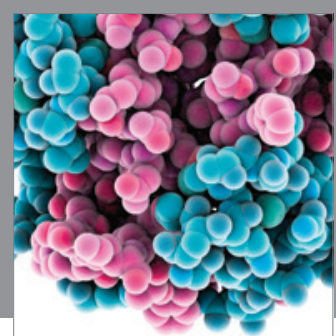

Journal of
Diabetes Research

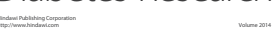

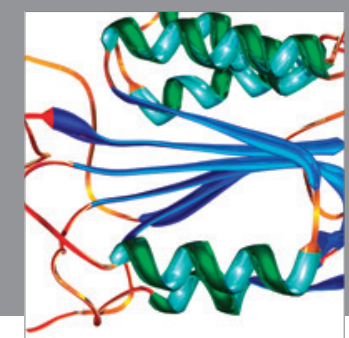

Disease Markers
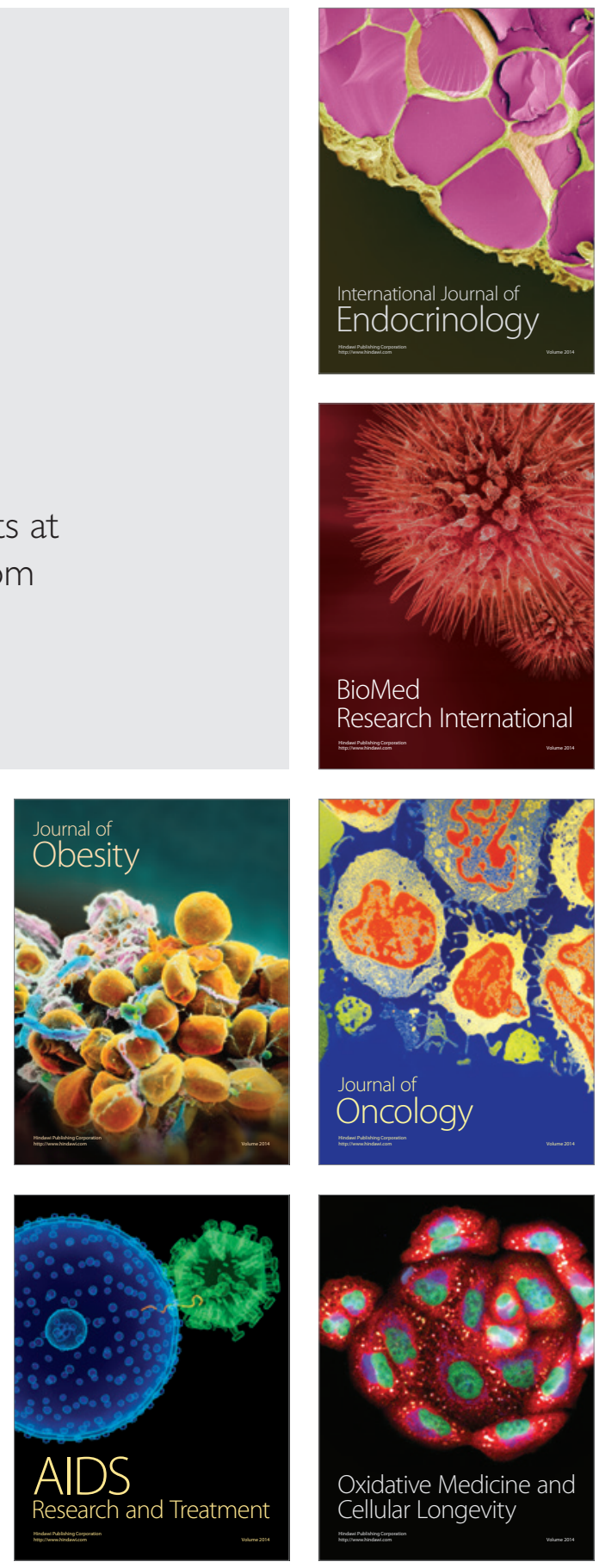